Maurer School of Law: Indiana University

Digital Repository@Maurer Law

Indiana Law Journal

Volume 34 | Issue 4

Article 4

Summer 1959

\title{
The Comparison of Soviet and American Law
}

Harold J. Berman

Harvard University School of Law

Follow this and additional works at: https://www.repository.law.indiana.edu/ilj

Part of the Comparative and Foreign Law Commons

\section{Recommended Citation}

Berman, Harold J. (1959) "The Comparison of Soviet and American Law," Indiana Law Journal: Vol. 34 :

Iss. 4 , Article 4.

Available at: https://www.repository.law.indiana.edu/ilj/vol34/iss4/4

This Lecture is brought to you for free and open access

by the Law School Journals at Digital Repository @

Maurer Law. It has been accepted for inclusion in Indiana

Law Journal by an authorized editor of Digital Repository

@ Maurer Law. For more information, please contact

rvaughan@indiana.edu.

\section{$\Psi$}

JEROME HALL LAW LIBRARY

INDIANA UNIVERSITY

Maurer School of Law
Bloomington 


\title{
THE COMPARISON OF SOVIET AND AMERICAN LAW
}

\author{
Harold J. Berman $\dagger$
}

"The science [of law] has been degraded to a national legal science. A humiliating, unworthy form for a science!" So wrote the great German jurist von Jhering more than a century ago. ${ }^{1}$

Are we seriously interested in developing a science of law-not, of course, in the narrow sense of the term science, but in the broader sense of a coherent body of knowledge about the nature of law, its principles of development, its social functions, its relationship to political, economic, religious and other ideas and institutions? If we are, we must study more than one legal system. ${ }^{2}$ If we are not, the study of foreign law will be superficial and even aangerous, for without legal philosophy, without legal history, without legal sociology, we shall misunderstand foreign legal institutions. In the case of our own law, we acquire some feeling, at least, of its philosophy, its principles of development, its functions, its social and historical background, from our general education and from our daily experience; though we may be unable to articulate its major premises we nevertheless have a sense of them, an awareness of their existence. The danger in studying a foreign legal system is that we will uncritically transfer to it the assumptions which we make about the underlying foundations of our own system; therefore we are compelled, in studying a foreign system, to undertake the difficult task of analyzing its foundations.

It is because the study of diverse legal systems compels the articulation of their underlying premises that comparative law is both important and exciting. To observe that American judges attach more authority to previous judicial decisions than do French judges is merely interesting, at most; but to relate that fact to the social and political role of the

$\dagger$ Professor of Law, Harvard University Law School.

1. von JHERING, Der Geist Des RöMISCHEN ReCHTS, I, 15 (1852).

2. One of the earliest and best statements of this point is that of Feuerbacr, KIEINe Schriften verimscerten InHaltes 163 (1833): "Why does the legal scholar not yet have a comparative jurisprudence? The richest source of all discoveries in every empirical science is comparison and combination. Only by manifold contrasts the contrary becomes completely clear; only by the observation of similarities and differences and the reasons for both may the peculiarity and inner nature of each thing be thoroughly established. Just as from the comparison of languages the philosophy of language, the science of linguistics itself, is produced; so from the comparison of the laws and legal customs of nations of all times and places, both the most nearly related and the most remote, is produced universal jurisprudence, the pure science of laws, which alone can infuse real and vigorous life into the specific legal science of any particular country." 
judiciary, the method of selection of judges, and similar factors in the two countries, is to make what Whitehead calls "inert" knowledge come to life. Similarly, a comparison of the Continental European system of indictment of crimes after extensive preliminary investigation by an examining magistrate with the Anglo-American system of indictment is an empty academic exercise until it is related to the role of the official in Continental European countries, the inquisitorial tradition, attitudes toward crime and criminals, the political significance of the writ of habeas corpus in English and American history, and like matters. When such relationships are drawn, they illuminate the entire law.

It is true that where two countries have similar legal systems, similar political, economic and social structures, and similar traditions the mere comparison of legal rules and institutions, without explicit consideration of the entire legal and social structure which surrounds them, may serve an important practical function. No better example of this can be found than in the comparative study of judicial decisions and statutes in our own states-undertaken every day in our law schools as well as in our courts and legislatures. Thus we may profitably compare the personal injury law of Indiana and the personal injury law of Massachusetts, taking for granted that social conditions, habits, values, and the like, as well as the technique and theory of the law, are basically the same in both states. By the same token, however, such comparative studies yield relatively meager results for the development of legal science in the broad sense in which I have used that phrase.

On the other hand, when two countries have legal and social systems which are entirely different in character, it becomes extremely difficult to find appropriate criteria of comparison. Llewellyn and Hoebel, in their study of the law of the Cheyenne Indians, ${ }^{3}$ were able to derive significant insights regarding the nature of law, but those insights were necessarily on a very high level of generality and hence are not readily applicable to the specific problems of more mature legal systems. Their demonstration, for example, that it is a basic function of Cheyenne adjudication to "kill off the grievance tensions" which are engendered by dispute suggests an important avenue of inquiry for the study of any system of law. But the way in which that function is performed in a primitive tribe which has no professional lawyers and no written records, which uses horses rather than money as the chief measure of value, which makes no explicit distinction between criminal and civil cases, and so forth, offers only a few guides to how such an inquiry should be conducted and by

3. Lleweliyn and Hoebel, The Cheyenne Way (1941). 
what standards it should be tested in dealing with a complex legal system such as our own.

Clearly, then, the particular value to be gained from the comparative method of study of law depends upon what legal systems are chosen for comparison. The study of primitive law helps us to find a broad anthropological and psychological basis for analysis of more complex legal systems. The comparison of diversities among states in a single federation helps us to test the merits of alternative solutions to relatively narrow (although often quite important) questions. In between these two extremes is the comparative study of legal systems within Western Civilization. This has been the traditional focus of comparative law as studied and taught in our law schools. It offers a very good basis for broad comparisons of a sociological nature as well as for narrower analysis of alternative solutions to specific practical and theoretical legal problems. Yet it also has certain limitations from both points of view. The legal and social systems of the various countries of the West are sufficiently different from each other to make direct borrowing of legal rules and techniques very difficult; they are, on the other hand, sufficiently similar in their basic structure and in their underlying philosophy to confine sociological analysis to what is, in many respects, a single culture. For despite the inroads of nationalism in recent centuries, there remains a strong family likeness in the legal systems of the various nations of the West; in the words of Edmund Burke, "the law of every country of Europe is derived from the same sources."

\section{Features of Soviet Law}

In analyzing the common foundations of Western legal systems, it is important, and perhaps even necessary, to view them from the perspective of a non-Western culture; and here the study of Russian law can be extremely valuable. For the law of Soviet Russia has many links with Western legal systems, and yet it has its roots elsewhere. It deals with problems very similar to those which confront our law-housing, automobile accidents, workmen's compensation, mass distribution of goods, family disorganization, inheritance, theft, homicide, and many others; and its legal solutions to these problems are in many respects similar to ours. Yet its roots are in a Communist political and social system, in a centrally planned economy, and in the historical tradition of Russia, with its Byzantine, Mongol, and Russian Orthodox heritage, on the one hand, and its window to the West, its adoption of Western institutions, on the other. 
Let me speak first of some of the features of Soviet law which are more or less common to Western legal systems. Soviet law is found in constitutions, in legislation, in administrative regulations, and in judicial decisions-although the boundaries between these different forms of law are not as precise as in Western systems generally. The Soviet judicial system includes trial and appellate courts of general jurisdiction within each of the fifteen union republics, with a single all-union court, the Supreme Court of the U.S.S.R. Also there is a separate system of permanent military courts in the nine military districts into which the country is divided, culminating in the Military Division of the Supreme Court of the U.S.S.R. The basic instruments of Soviet criminal and civil law and of judicial procedure are in the form of codes (in addition to the criminal code, code of criminal procedure, civil code, and code of civil procedure, there is also a family code, a labor code, and a land code); these codes are republican, rather than all-union, but the differences from republic to republic are slight, inasmuch as the codes of the Russian Republic served as a model for the other republics and inasmuch as all the codes are subject to all-union legislation. There are a substantial number of lawyers in the Soviet Union-some 60 to 70 thousand-as well as law-trained notaries who draw contracts, wills and other documents. A substantial amount of litigation is conducted in the courts over such matters as housing, divorce and alimony, workmen's compensation, discharge of workers, property rights in houses and other property which may be personally owned, inheritance, author's royalties, personal injury, and other similar matters. In addition, a special system of courts called Gosarbitrazh (literally, state arbitration) decides some 400,000 cases a year involving contract disputes between state business enterprises, which are juridical persons with stubstantial powers of disposition of goods and a limited power of disposition of capital.

Soviet criminal and civil procedure follow the pattern set by the Western European systems, a pattern which came into Russian history with the judiciary reforms of 1864 . In contrast to Anglo-American law, the Soviet system of indictment of crimes-like the French, German, Italian and others-provides for investigation by an examining magistrate, who questions the suspects and witnesses at length over a period of time and presents the indictment. Trial both of criminal and civil cases is by a court consisting of a single professional judge and two lay judges, called people's assessors, who are chosen from the population to sit for ten days out of a year. In a criminal case the burden of proof of the allegations of the indictment is upon the prosecution, and the accused is 
entitled to a defense counsel. ${ }^{4}$ There is a right of appeal in civil and criminal cases; the appeal is heard by a court consisting of three professional judges. Review of the appellate court's decision by a still higher court is discretionary.

What I have been describing thus far are certain surface features of Soviet law. Of course we are concerned with what lies behind the surface. But the surface is also important, for it gives us a key to unlock the first door to what lies behind. An American law student does not have to feel entirely lost in starting out, at least, to understand Soviet law. He can read opinions of Soviet judges in decided cases-many of them have, in fact, been translated into English by American scholars. $\mathrm{He}$ can read legislative materials and codes which speak a language familiar to him-a language of property, contract, negligence, unjust enrichment, intent of the parties, fault, statute of limitations, right of appeal, burden of proof, damages, criminal intent, criminal negligence, right of self-defense, right to counsel, and, in general, the entire apparatus of concepts and institutions of Western legal systems. He can read treatises and textbooks by Soviet law professors-provided he knows Russian-written for the benefit of the Soviet legal profession (including judges and prosecutors) and of law students in the thirty-two Soviet universities, expounding and commenting on the various branches of Soviet law in a manner in many respects similar to that of treatises and textbooks with which he is familiar. The Amercian student will confront serious problems in using these materials-including problems arising from their paucity as compared with ours, from the fact that some Soviet laws are unpublished, from the fact that much of Soviet legal literature is colored by Party jargon and from the fact that writers and courts are bound by Party policies which are not always explicitly stated. One must learn to read between the lines of Soviet writings. Yet it is of considerable value that the lines are there.

\section{Technigues of Adjudication and Legislation}

What lies behind this first door? Let us turn first to techniques of

4. Until recently the accused was not entitled to defense counsel prior to trial. The Fundamental Principles of Crinninal Procedure adopted by the Supreme Soviet of the U.S.S.R. in December 1958 provide for defense counsel after the preliminary examination is completed, but before the indictment is finally ready to be presented to the court. This means that counsel may petition the investigator to conduct further inquiries or to amend the first draft of the indictment and may contest it in the preliminary session of the court prior to trial. Also the Fundamental Principles provide that the investigator has discretion to admit counsel at earlier stages of the investigation. See Fundanental Principles of Criminal Procedure in the USSR and the Union Republics, Pravda, December 26, 1958, Arts. 22, 23, translated in 11 Current Digest of the Soviet Press, no. 4, p. 7, March 4, 1959. 
adjudication. Here the American lawyer does not feel nearly as much at home as would the French or German or Italian lawyer-though they, too, would encounter some surprises. Soviet adjudication is distinguished by its informality. A civil action is commenced by a written complaint which need state very little and may state as much as the plaintiff wishes. No written reply is required. There is no set procedure for formulating issues in advance of trial and no pretrial procedure for taking depositions or procuring documents. As in Continental European countries, the trial may continue at intervals over weeks or even months. The judge and, if they wish (which they seldom do), the two assessors take the leading role in questioning the parties and the witnesses, although the lawyers (and also the parties themselves) may interrupt with questions. There are no rules of exclusion of evidence; however, the judges are supposed to be guided by rules of evaluation of evidence. In criminal cases the complaining witness may also claim his damages for losses which he suffered as a result of the crime; again, the pattern is European. Upon appeal the case is, in effect, retried. The informality of the proceedings is emphasized by the fact that in a great many civil cases the parties prefer not to be represented by counsel.

The informality of civil trial procedure is bound up, of course, with the absence of the jury; both are connected with the conception of the trial primarily as an official investigation of the truth of the claims and defenses presented, rather than primarily as a forum for achieving justice through the clash of adversaries. This, too, is European-to a much lesser extent, English-and quite un-American. But the informality of Soviet civil and criminal trial procedure is also connected with a special feature of Soviet law, the paternal relationship of the judge to the parties; the Soviet judge is supposed to guide and discipline the parties and to help inculcate in them the attitudes and beliefs which the State seeks to encourage. (About this I shall have more to add later).

Soviet judges are not bound by precedent and indeed it is prohibited by Soviet law for the lawyers to cite precedents. Statements of law by higher courts in decided cases, and especially by the Supreme Court of the U.S.S.R. are, however, binding upon lower courts; therefore Soviet lawyers can and do cite such statements. The difference is a subtle one. The distinction between the development of law by analogy of previous decisions and the development by analogy of code provisions, statutes, and doctrine may be of little practical importance to the outcome of a particular case. The absence of a doctrine of precedent in Soviet law is nevertheless significant in that it reflects the absence of a strong sense of the growth of law over time. There has been some organic development 
of legal doctrine in the Soviet Union, but on the whole Soviet legal development has been more fitful, and in many areas of law there have been wide swings back and forth. One wonders in any event whether the doctrine of precedent, in its strict form at least, could possibly be introduced into a system such as the Soviet, in view of the informality of pleadings. Without precision in the formulation of issues, it is impossible to achieve precision in the distinction between holding and dictum.

Finally, with regard to Soviet techniques of adjudication, it must be noted that Soviet judicial opinions reflect a rather mechanical mode of reasoning, a conceptual rather than a pragmatic logic. All flavor of "sociological jurisprudence" is missing from them. Law seems to be conceived in terms of fixed rules; its application is viewed as requiring accuracy, not policy. The opinions are short. Occasionally the facts of the case are developed at length, but rarely is there any elaborate discussion of the law. The opinion has more the form of a decree, and indeed is entitled a "decree" (postanovlenie). Typically it is in the following style: "This case is governed by Article Such-and-such. The contention that that provision is superseded by the statute of such-and-such date is unfounded, since the statute does not refer to that provision." And so on. On the other hand, where it is conceived that there is a gap in the law, the Soviet courts often do not hesitate to fill it. In fact Soviet codes and statutes are full of lacunae, and as a result much of Soviet law is avowedly judge-made. For example, the Soviet courts, without any code or statutory provision on the subject, early decided that damages awarded in tort cases for loss of earning capacity should be paid in the form of annuities, and should cease to be paid if the plaintiff subsequently recovered his earning capacity. We know this practice in workmen's compensation, of course, but the Soviet judges introduced it in tort actions generally. Indeed, most of Soviet tort law has been spun judicially out of a few broad code provisions. To cite an even more striking example, workers found guilty under a law (repealed in 1956) imposing two-tofour months' imprisonment for quitting a job without permission of management, were held by the courts to be not obliged to return to the former job after serving their sentence, on the ground that by quitting, though unlawfully, they had dissolved the labor contract. This was surely "mechanical jurisprudence," though it made new law. Incidentally, the decision provided a strong incentive for otherwise reluctant managers to give insistent workers permission to quit.

Mechanical jurisprudence-in the sense of a logic which tends to read legal propositions literally, rather than in terms of their social purpose-is connected in Soviet law with the movement toward stability 
which began in the early 1930's and which has gathered considerable momentum since Stalin's death six years ago. Earlier Soviet jurisprudence had taught that law and policy are virtually indistinguishable, and that Soviet law in the period of construction of socialism should have maximum flexibility. Article 1 of the Civil Code of 1922, providing that rights are to be protected only to the extent that they are exercised in accordance with their social economic purpose, and Article 16 of the Criminal Code of 1926 , providing that a socially dangerous act, though not specifically proscribed, may by analogy be punished under a provision proscribing similar acts, were reflections of the earlier conception of law as policy science. Since the mid-1930's these provisions have become obsolete. Article 1 has been severely restricted and the doctrine of analogy has been expressly repudiated. The reasons for this shift toward what Stalin in 1936 called "stability of laws" and "strict socialist legality" are complex. They are connected with a stabilization of social life generally, the strengthening of the family, the restoration of military traditions, the emphasis on the achievements of pre-revolutionary Russian history, and, in the economic sphere, a recognition that efficiency in an industrial society requires the kind of calculability and predictability which only a stable legal system can provide. Under Stalin legal stability did not extend to the political area and to a lesser extent the same is true under Stalin's successors. Where the top leadership has felt its own security threatened, it has resorted to terror-terror by abuse of law and naked terror without law. But in areas of social and economic life in which the supremacy of the Party leadership was not challenged, Stalin discovered that his dictatorial powers could be maintained more effectively with a system of law than without it. The dictator can easily enact statutes; his problem is to establish a system for their interpretation and application in a manner consistent with his will. For this purpose mechanical jurisprudence is safer than a more creative approach-safer for the leadership and safer also, and perhaps primarily, for the judges and lawyers.

Thus Soviet techniques of adjudication lead us to Soviet techniques of legislation. As in France after the French Revolution, so in the Soviet Union, restrictions on the doctrine of precedent as well as on liberal judicial interpretation of statutes are seen in terms of legislative supremacy. The difference is, however, that the Soviet legislature, the Supreme Soviet of the U.S.S.R., is hand-picked by the top leadership of the Communist Party, and its freedom of debate is extremely narrow. Only recently has there begun to function a committee system; there are now some thirteen standing committees for drafting legislation in various 
fields. But the initiative is with the Party leaders, and it is they who set the limits of possible action. It is the absence of due process of legislation, the absence of a genuine adversary system of enacting statutory law, which is the chief formal distinction between the Soviet legal system and the legal systems of the West. Here we find one of the principal links between Soviet law and Soviet autocracy.

The de facto legislative power of the top Soviet leader or group of leaders reflects a fundamental difference between the nature and function of law in the Soviet Union and in the West. It is a basic postulate of all Western systems that law is essentially a means whereby society exercises control over the political leadership; it is a basic postulate of the Soviet system, on the other hand, that law is essentially a means whereby the political leadership exercsies control over society. We must remember, in this connection, that Russia has never had a deep-rooted tradition of a system of law which binds the ruler himself.

\section{Soviet Law and Social Order}

We must not confuse the rule of law, however, with the role of law. Despite their initial hostility to law both in theory and in practice, the leaders of the Russian Revolution learned, as leaders of the western revolutions in earlier centuries had learned, that the principles for which the Revolution was fought cannot be preserved unless they are institutionalized in law. In particular, the Soviet leaders learned that the system of planned economy cannot function without law; and they learned that a collectivized-one might better say, a mobilized-social order requires law.

Let me speak briefly first about the law of a planned economy. Soviet industry and commerce are largely in the hands of state agencies; and Soviet agriculture is under stringent state control. The plans under which the state officials who are thus in charge of Soviet economic activities operate come from higher administrative authorities and ultimately from the Council of Ministers of the U.S.S.R. and its State Planning Committee. Yet plans are not self-executing. It is all very well for Moscow to say, or for the new regional economic councils to say, that so much coal, so much steel, so many pairs of shoes, so many television sets, should be produced; but where are the managers to get the necessary resources to produce them? Labor must be paid; goods must be procured; the product must be distributed. The bottlenecks of planning are insuperable unless a rational system of incentives, of criteria which will guide individual decisions, is worked out. The Soviet leaders in the late 1930's worked out such a system-worked it out in orthodox terms of 
monetary rewards, contract law, corporate autonomy of individual enterprises, and in the case of the collective farms, cooperative sharing in the profits of the collective as well as personal ownership by the peasants of their household plots.

I have mentioned that there is a great deal of contract litigation between state business enterprises. Gosarbitrazh adjudicates disputes arising over failure to deliver, breach of warranty, and similar questions. The individual state enterprise has the same incentive to sue for breach of contract that a private firm in this country has: its losses will come out of its profits, a portion of which goes into bonuses. In addition there is an added incentive: if it can show that its failure to fulfill the plan is due to the fault of another enterprise, it can escape measures of administrative discipline. Finally, the State itself has a strong interest in an impartial determination of responsibility, as well as in the correction of the causes of breach of contract. Indeed, one of the most interesting aspects of the work of Gosarbitrazh is its educational role in so-called pre-contract disputes. If the parties cannot agree upon the terms of a contract which, under the general plan, they ought to conclude, they may resort to Gosarbitrazh which will determine how the contract should be written. It is apparent that here contract law and administrative law are intertwined, and that although Soviet contract law is often quite similar to our own in terms of the rules of formation, breach, damages, and the like, it fulfills a quite different function.

Finally, I should like to say a few words about the functions of Soviet law in maintaining a collective social order. In comparison with the United States, Soviet society is more highly mobilized, more highly directed, not only for military purposes but also for social and economic purposes. It is the idea of Soviet society that each person in it must have a place, a job to do. The legal system is more immediately concerned than ours, therefore, with the allocation of duties, and although rights are of course correlative with duties, it is implicit in Soviet law that duties precede rights, that rights arise out of duties.

How is this manifested concretely? In the first place, it is manifested in the increased role of criminal law. The concept of "official crimes"-intentional or negligent abuse of authority by persons in responsible positions-plays a very important part in the control of the economic behavior not only of managers of state enterprises but even of persons quite far down in the official hierarchy, including, for example, waiters in state-owned restaurants. From 1940 until 1956 workers who quit their jobs without authorization of management were subject to two-to-four months' imprisonment. Recently in several of the smaller 
republics a law has been enacted whereby a person who is considered an "anti-social and parasitic element" may be exiled from two to five years to another part of the republic by an ad hoc body of neighbors with review by the executive authorities only. ${ }^{5}$

The role of law in maintaining a mobilized social order is seen also in the powers of the Procuracy not only to prosecute crime but also to supervise generally the legality of administrative acts. The general supervisory powers of the Procuracy make it the watchdog of the central government; it may protest any illegality of management, of local government, or of individual officials, to the next higher administrative authorities. Although the institution of the Procuracy is known also to other countries, only in Russia has it played so crucial a role in maintaining social order in general.

The Soviet courts, too, play an important part in maintaining the sense of collective unity and collective purpose in the society. Their task is conceived to a large extent in terms of educating people-the parties, the spectators, and the whole society-to be the kind of "new Soviet man" which the state is seeking to develop: hard-working, honest, resourceful, cooperative, and above all conscious of his membership in a socialist society and loyal to its leadership. Both substantive and procedural law manifest a jurisprudence in which the balancing of interests yields place to the shaping of interests. It is not merely that Soviet judicial decisions are thought to have an educational function, but rather that the educational purpose of judicial decisions becomes a central factor in the determination of rights and duties in particular cases. An American parallel may be found in the laws governing juvenile delinquency: here we are expressly concerned primarily with the effect of procedures and of decisions upon the person before the court. Something of the spirit of the law governing juvenile delinquency is carried over into all branches of law, civil and administrative as well as criminal, in the Soviet Union. This is not to say that Soviet law is benign. It is benign in some respects and ruthless in others. And it is not necessary to stress that the whole conception of a parental relation between the court, as an arm of the state, and the people as its wards, so to speak, lends itself to arbitrariness, to political interference in adjudication, and to a philosophy of historical relativism under which rights may be withdrawn altogether if circumstances so require. ${ }^{\circ}$

5. See Berman, Soviet Law Reform-Dateline Moscow 1957, 66 YALE L.J. 1191, 1208-09 (1957). The "parasite law" has been widely discussed, pro and con, in the Soviet press, since 1957. It has not yet been adopted, as of this writing, in the largest Soviet republic, the RSFSR.

6. Id. at 1214-15. 
Yet it is a mistake to view Soviet law as merely an instrument of dictatorship. It is a genuine response to the crisis of the 20th century, which has witnessed the breakdown of individualism-in law as well as in other areas of spiritual life. "Where today are the economically selfsufficient household and neighborhoods, where is the economically selfsufficient, versatile, restless, self-reliant man, freely making a place for himself by free self-assertion . . . ?" asked Roscoe Pound in 1930. "Where, indeed, but in our legal thinking in which it is so decisive an element." Tince 1930 it has gone out of much of our legal thinking as well. The excesses of totalitarianism can teach us the dangers of rushing to the opposite extreme; nevertheless this is not a matter where we can afford to be smug. Our own law may be seen in the light of Soviet experience, as seeking a level which combines the virtues of individuality and collectivity, while avoiding the mythology of either "ism."

7. Pound, The New Feudal System, 19 Ky. L.J. 1, 6 (1930). 